\title{
THE LIMITS OF ETHNOGRAPHY VERSUS THE POVERTY OF THEORY: \\ PATRON-CLIENT RELATIONS IN EUROPE RE-VISITED
}

\author{
Cris Shore
}

\section{ABSTRACT}

Calls for anthropology to move 'beyond ethnography' are not new, but the frequency of their utterance suggests that they tend to go unheeded. A question increasingly asked today is 'is it possible to do ethnography on an awkward scale'? (Comaroff and Comaroff 2003). In our increasingly globalized world, the material and moral conditions that animate local events are not easily captured by the ethnographer's lens. In a recent critique, Paul Willis (2002) chastises anthropology for its lingering empiricism and persistent humanism, concluding with a plea for more 'theoretically informed ethnographic studies'. This paper shares these concerns. Too often 'social anthropology' (the study of human cultures and societies in its broadest sense) is conflated with 'ethnography', understood either as the process of participant-observation or fieldwork, or as the textual product arising from that experience: a case of the methodological tail wagging the theoretical dog. This paper sets out to demonstrate why going 'beyond ethnography' is necessary if we are to transcend the constraints of empiricism and make sense of wider socio-cultural patterns and processes. I illustrate my argument by reference to the European Commission, the European Union's civil service, and the strengths and limitations of ethnography for understanding its complexity. While most local, 'insider' and ethnographic accounts highlight the hybrid nature and 'uniqueness' of the Commission's organizational culture - and still define the EU as an 'inter-governmental' body - I argue that a very different picture emerges when we use a wider theoretical lens that takes into account class and political economy perspectives. I also show how debates over EU institutions recall anthropological arguments over the analysis of patron-client relations: i.e. what appears from an ethnographic perspective as a loose set of inter-personal ties between individuals of unequal status and wealth often turns out to be, on reflection, an emergent class system and the beginnings of a process of state-formation. 
INTRODUCTION: 'THE NATIVE'S POINT OF VIEW' AND THE LIMITS OF ETHNOGRAPHY

This paper sets out to develop a point raised at the end of the Call for Papers setting out the agenda for the $2005 \mathrm{ASAA} / \mathrm{NZ}$ conference; to 'rethink previous ethnographic research and the theoretical frameworks used to interpret it.' The ethnography in question is my own study of European Union (EU) civil servants, which I embarked on in two periods of fieldwork in 1992 and between 1995-97 (see Shore 1993; 2000). Despite having spent much of the past decade and a half analyzing and writing about the EU, one question has always eluded me and, to date, remains curiously unanswered: what exactly is this enigmatic entity called the EU? In order to answer that question, I would like to revisit a theoretical debate within anthropology that I first encountered in the late 1970 in the ethnographic literature on patron-client relations. However, my goal is not so much to 'rethink' that literature or the theoretical models of the 1970s, but rather to show how the anthropological critique of patron-client relations can be re-worked in order to shed light on contemporary forms of power and systems of government.

The themes of 'patronage' and 'clientelism' had a particular salience in the anthropology of the Mediterranean: early ethnographic accounts of Mediterranean societies highlighted the importance of individuals, 'entrepreneurs', networks, and institutions such as 'patronage', 'spiritual kinship' (i.e. godparenthood) and 'instrumental friendship'. The patron-client relationship was identified as key feature of peasant societies, and an example of what Eric Wolf (1966) termed the interstitial, complementary and parallel structures of complex society'. From an analytical perspective, Sydel Silverman summed it up as follows:

Patronage as a cross-cultural pattern may be defined as an informal contractual relationship between persons of unequal status and power, which imposes reciprocal obligations of a different kind on each of the parties. As a minimum, what is owed is protections and favour on the one hand and loyalty on the other. The relationship is on a personal, face-to-face basis, and it is a continuing one (Silverman 1965:176).

What interested the pioneers of Mediterranean anthropology (including Pitt Rivers 1961, Peristiany 1968, Campbell 1964, Kenny 1968 and Silverman 1965) was precisely the moral quality of these patron-client relationships. This entailed peasants, share-croppers, shepherds and other lower-status and sub- 
ordinate groups, giving services and political support to their higher-status patrons (who typically included the local priest, doctor, mayor, landlord and merchants) in return for small favours, political protection and support in dealing with the wider world beyond the village. Although the relationships were clearly unequal and hierarchical, it was the ethical, moral, multi-stranded or 'multiplex' (see Bailey 1971) character of these relationships that became the focus of anthropological interest. As many ethnographies noted, it was usually the peasant or supplicant - not the powerful priest or mayor or landlord - who would try to create the patron-client bond. Drawing the powerful magnate into a more personal relationship was seen as a 'weapon of the weak'; a way of controlling the 'autocracy of local magnates' (Davis 1977:135) and of creating more binding moral ties that the subaltern partner could exploit for strategic familial advantage.

Most patronage in the Mediterranean involved relationships between individuals rather than groups. Typically, men would be clients to those above them, while simultaneously patronizing their social inferiors. What these early anthropologists saw, therefore, were a series of inter-personal ties (or 'dyadic' bonds as they were termed), which, when seen as a whole, formed chains or networks linking the rural hinterland to the metropolitan centres. From this perspective, local patrons came to be defined by Silverman (1965) and others as 'community-nation mediators'. Patrons were 'middlemen' or cultural brokers' who straddled the urban-rural divide: individuals who helped to 'bridge the gap' between core and periphery, or what Robert Redfield called the 'Great' and 'Little Traditions' - so that isolated rural communities might have access to the benefits of the state.

Mediterranean rural societies were marked by a strong ethos of egalitarianism summed up in the Greek saying, 'we are all equal here' and in the Kabyle male maxim, 'I too have a moustache. When asked about these patronage relations, Mediterranean countrymen would typically describe them as an extension of 'friendship' and 'kinship', or as a spiritual relationship, describing the patron as 'my friend', or 'the godfather (compadre) of our daughter.' Taking their cue from their informants, many anthropologists used similar interpretations in their ethnographies. 'Lop-sided friendship' and 'reciprocal but unequal' was how Julian Pitt Rivers (1961:140) famously portrayed the patron-client relationship in his pioneering ethnography of a small Spanish town. The chains created by these patronage ties were variously described as 'informal groups', 'action sets', 'friends of friends', 'kinship networks' and 'amigocracies' (see Boissevain 1974). 
I use this example because it illustrates some of the limitations of fieldwork and why anthropological analysis needs to go beyond ethnography if it is to penetrate beneath the surface of what appears to be the 'ethnographic reality'. The problem in this case was not 'ethnocentrism' but what we might term 'displaced' or 'secondary ethnocentrism. This tends to occur when anthropologists are so desperate to divest themselves of the charge of being 'ethnocentric' (ever a damning slur in professional anthropological circles) that they become uncritical advocates for the perspectives and explanations of their local informants, so that their explanations of reality are regarded as somehow less biased and necessarily closer to the anthropological 'truth'. Paul Willis (1997), reflecting on this problem, gives a slightly different twist to this argument. Anthropologists, he argues, are still plagued by two lingering problems. The first is that of 'empiricism', or the belief that 'reality is indeed simply written on its surface' and that 'all you need to know to understand about the field is in some way in the field' (Willis 1997:184). The second is the problem of 'centred humanism, by which he means the assumption that agents in the field are in charge of their own destiny in some way or another: 'It might look traditional, irrational, old-fashioned, religious or whatever, but your job is to show the real truth, to show that ultimately, another people's culture is human and rational, with centred human beings in some way controlling their own forms' (1997:184).

In the case of Mediterranean patronage, that empiricism and humanism made it difficult for ethnographers to see that what they were looking at were not just so many individual ties or 'dyadic bonds' linked together in a loose chain, but unequal power relations of an historical and structural nature. It was only when looked at from a Marxist and materialist perspective that it became possible to diagnose these relationships as class relationships and to see that 'spiritual kinship' and 'friendship' were simply idioms of stratification used to ameliorate or disguise what were, in effect, relationships of domination and subordination (see Davis 1975; Colclough 1971; Li Causi 1975). As Davis wrote:

Patronage thus occurs whenever men adopt a posture of deference to those more powerful than they and gain access to resources as a result. It is associated with honour because honour is a moral code in which rich and poor are ranked and in which their interdependence is emphasized as in no other idiom of stratification; because the language of honour is that used by the weak to mitigate the consequences of their helplessness in this relationship; and because honour aids choice: it is at least potentially an absolute differentiator; 
and a patron, choosing among several would-be clients, chooses the more honourable (Davis 1977:132).

The discourse of 'honour' and 'friendship' - like that of 'dyadic bonds' and 'inter-personal ties' - served to conceal rather than illuminate the class nature of the relationships. Yet most anthropologists, blinded by what they saw as 'ego-centred coalitions', personal ties, and the voluntary, contractual and moral quality of the patron-client relation, failed to see honour as ideology rather than empirical fact. The evidence of class exploitation was sometimes overwhelming. For example, Cutileiro's (1971) study of the Portuguese village, Vila Velha, noted that some 95 per cent of adult males were so poor they were unable to provide adequately for their families; 'and among the labourers it had been accepted until about 1960 that their women would copulate with their honour superiors - with employers and rich shopkeepers - without detracting further from their honour' (Davis 1977: 92).

The problem of ideology in ethnographic analysis - like that of 'displaced' or 'secondary ethnocentrism' - has ramifications far beyond Europe and the Mediterranean, as Talal Asad (1972) found in an equally trenchant critique of Fredrik Barth's study of the political organization of the Swat Pathans in Afghanistan. Whereas Barth's transactionalist study led him to argue that Swat society was basically acephalous, fluid and highly volatile, (from which he concluded that Swat tribesmen, as clients of local landlords, were able to choose between various potential patrons who they wished to offer their allegiance to), Asad showed how partial, flawed and a-historical this analysis was. His point here is simply that the ethnographic lens often fails to capture the complexity of those social relationships and conditions that have to be understood from a more temporal and holistic perspective.

Following Philippe Descola (1992:9), I would argue that 'ethnography' is something distinct from ethnology and anthropology. Ethnography is about collections of data. Ethhnology is concerned with the comparative analysis of those data. And anthropology proper is concerned with making sense of wider patterns of social life and cultural variability. The problem, however, is that these levels of analysis are often conflated. Ethnography is typically presented as the be all and end all of anthropology, the approach that distinguishes our profession from (un-grounded and abstract) disciplines like sociology or cultural studies. But if we define the scope of anthropology in terms of fieldwork, then we rule out a vast range of human affairs as subjects of anthropological enquiry. That would mean abandoning anthropology's claim to being the study of 'all human cultures and society'. If the ontological imperative of 'being there' 
dictates what we can legitimately study or write about, then this really does become a case of the methodological tail wagging the theoretical dog.

An anthropology that seeks to understand elites, policy professionals and modern forms of power (i.e. 'studying up'), has to move beyond the cannons of conventional ethnographic fieldwork. There are many phenomena in the world that are not 'easily captured by the ethnographer's lens'. This is what Comaroff and Comaroff (2003) have termed the problem of 'ethnography on an awkward scale. In a world where it is increasingly recognized that it is impossible to capture in any one place the totality of relations of a 'society', or the essential workings of 'a culture', they ask 'what kind of methods are appropriate' (Comaroff and Comaroff 2003: 153)? This problem, however, is hardly new. Writing over three decades ago, Laura Nader (1972) called into question the salience of 'participant observation' as the be all and end all of anthropological enquiry. Its 'fetishization', she suggested, 'was driving anthropologists to focus on small-scale societies, and therefore blocking work on the most relevant problems of the world' (Brown 2005:26).

Those who have been involved in developing an 'anthropology of policy' have long argued that we need to adopt a radically different conception of the 'field'; not as some kind of bounded geographical space or fixed community, but rather as a multi-sited configuration of actors, agents and institutions all connected by, and through, particular policy processes (Shore and Wright 1997; Wedel et al 2005).

\section{CASE STUDY: THE ENIGMA OF THE EUROPEAN UNION}

What is ethnographically interesting about the EU is its sheer complexity. At the organizational level, and as a set of legal rules and regulations, the EU is baroque and labyrinthine. It is also continually evolving through the combined processes of enlargement (with the accession of new member states) and the steady expansion of the EU's areas of competence (which are summed up in the EU's so-called 'acquis communautaire', or patrimony of laws and regulations). This makes defining the EU curiously problematic, even for EU analysts and those who work for it.

Within the EU and European Studies, this problem was famously captured in a seminal article written by American political scientist, Donald J. Puchala (1972), in what has come to be known as 'Puchala's elephant parable' - although the story of blind men and an elephant that it draws on is a well-known parable believed to be of Indian origin. The story goes something like this. 
Three blind men, who have never encountered an elephant before, are each asked to touch part of an elephant and describe what sort of animal is in front of them: one touches its trunk, another its tail, and the third its tusk. Each therefore ends up with an utterly different description of what is before them; one compares the elephant with a snake, the other a rope, while the third says it resembles a spear. None manage to grasp the animal as a whole, yet all of them make reasoned deductions based on first-hand experience.

Puchala's elephant parable has become a widely used metaphor within the EU Studies literature, but it is also highlights another problem prevalent in much of the EU scholarship, namely, the tendency to treat the EU as a kind of blank canvass - which is then perceived and defined through the lens of people's hopes, fears and fantasies. Thus, for many people in Eastern Europe, the EU stands for 'progress' and 'modernity' (and of course, escape from the hegemony of Russia). At a seminar at Harvard University, I once heard the ambassadors for Lithuania and Poland explain how, for many of their fellow countrymen, membership of the EU symbolized joining the 'West' - and union with America; for Spain Greece and Portugal, EU membership represented a bastion of democracy against the threat of dictatorship; for France, the Eurozone traditionally symbolized an extension of Francophonie; For Germany, EU membership represented a path to respectability and redemption - and a way of 'coming to terms' with its Nazi past; while for British Eurosceptics, the EU is seen as a continental menace and, as one EU official expressed it to me during fieldwork, a 'product of French greed, German guilt and Belgian opportunism' For many of Europe's emerging regions, the appeal of EU membership is also that it offers a way for them to circumvent the nation state and the domination of national government.

INTERPRETING THE EU: THE LIMITS OF EMPIRICISM - AND THE POVERTY OF THEORY

The problems encountered when we try to explain what the EU is (or what it is evolving into) are very similar to those raised in the anthropological debate over patron-client relations in Southern Europe. Like Puchala's elephant, the European Union is so large that it is difficult to grasp the whole entity from any singular or empirical perspective. We are confronted with an exemplary case of Comoroff and Comoroff's dilemma of how to conduct 'ethnography on an awkward scale'. As with the anthropological interpretation of patronage in the 1960 and 70 s, the danger of ethnographic empiricism is that we either fail to see the 'wood for the trees' or else naively assume that the 'whole' can be deduced from close ethnographic scrutiny of one small component part. The 
other danger is falling into the trap of 'secondary ethnocentrism' - of privileging (or failing to push our analysis beyond) the actor's frame of reference or 'natives' point of view'. On the other hand, and at the other extreme, there is equally a danger of excessive 'theoreticism'; of an over-reliance on abstract, models and disembodied positivistic theories that have little or no empirical grounding. This problem is particularly striking throughout much of the political science literature on the EU, as I shall illustrate in the pages that follow. Before turning to examine the way the EU has been theorized by political scientists, however, let us first consider what the EU looks like from the 'natives' point of view and how this helps us make sense of the EU enigma.

The civil servants and officials that I interviewed and socialized with during fieldwork appeared relatively unbothered by the awkward problem of defining the EU. For them, 'Europe' (to use the local Brussels idiom for the EU) was simultaneously a project, an ideal, a set of institutions and, more prosaically, their employer. ${ }^{1}$ When asked about the 'organizational culture' of the European civil service most interviewees stressed how unique the Commission was in relation to other public administrations, but also how different their unit or Directorate-General ('DG') was compared with others. They typically compared the Commission with national administrations (against which it was described as 'more cosmopolitan, polyglot and multicultural, but also more hierarchical, politicized, bureaucratic and disorganized). Besides the evident sense of affection and loyalty that came across when officials spoke about the Commission - and the recurrent use of the terms 'we' and 'the house' - what was particularly noticeable was the constant use of architectural and journeying metaphors when talking about the EU. As they saw it, Europe was something being 'built' every day in myriad ways, and they were a small part of that architecture (some saw themselves in quite exalted roles as 'pioneers' of the new Europe). However, the Europe they were building was an ideal, typically located in the future (cf. Abélès 200o). In terms of their relationships with their member states or countries of origin, most interviewees commented on how living in Brussels and working for the EU had changed them. It had broadened their outlook and had made them more 'European' in orientation. As I discovered during fieldwork, the word 'engrenage' (which translates as 'gears' or 'gearing') was the local idiom used to describe this process by which actors come to acquire a 'European way' of thinking and acting. Used in this sense, the term engrenage effectively meant 'becoming enmeshed' - an idea that embodies a whole theory of elite socialization and the process by which national officials come to be 'Europeanized' as a result of their exposure to the EU and its institutions. 
Secondly, we have the anthropological accounts; although few in number, most of these share the view that the EU is unique; that each DG has developed characteristics peculiar to itself; that the EU can only be meaningfully explained in its own terms, or from the 'natives point of view'. These themes were echoed in a report written by a team of Anthropologists who were employed by the European Commission to carry out a study of its own evolving organizational culture. According to that report, the Commission is an organizational 'hybrid' with a unique culture 'of compromise' and sense of identity:

Il exist en effet une culture proper à la Commission européene, et c'est sans doute l'adhésion à des notions e à des valeurs communes qui cimente les rapports entre ses members.... Partager cette culture, c'est aussi avoir le sentiment d'une identité commune. Cette identité englobante porte en elle cependant toutes sortes de segmentations (Abélès et al 1993:5-6).

While that report and a follow-up study by McDonald (1998) gave very good ethnographic accounts (or 'thick descriptions') of life inside the European Commission, what was conspicuously lacking was any kind of wider analytical framework or materialist perspective that might advance the analysis of the organization beyond these insider accounts, empirical observations and ethnographic vignettes. Part of the problem here lies precisely in the narrowly empirical (and some might say 'empiricist') perspective adopted by the authors. As McDonald wrote in the introduction of her later study:

The basic premise of this approach is that it is people's own perceptions of the world that determine their behaviour, and that if you want to understand why people behave as they do then you need to understand their own perceptions of the world and to do so in their own context (McDonald 1998:1).

But is this really the case? In most instances it is not people's perceptions of the world that 'determine their behaviour', but rather the historical, social, and material circumstances in which they live (i.e. their 'conditions of existence'). This is a point that Marx (among others) made long ago in his critique of idealist philosophy when he argued that it is not the consciousness of men that determines their being, but, on the contrary, their social being that determines their consciousness. ${ }^{2}$ Instead of treating people's perceptions as the explanatory factor behind human behaviour we need to go beyond this and ask, 'how are people's perceptions of the world constructed in the first place'? In many situations people's worldview and behaviour derive from historical 
and economic relations or organizational and cultural rules that lie beyond their immediate perception and comprehension. As the anthropological critique of patron-client relations showed, explanation does not necessarily lie at the level of empirical reality. This is a particularly important consideration when dealing with a complex institution like the European Union.

THEORISING THE EUROPEAN CONSTRUCTION: MUDDLES IN THE POLITICAL SCIENCE MODELS

By contrast with the anthropological and ethnographic literature, much of the political science and international relations literature tends to be highly abstract, theoretical and lacking in empirical data. The EU is frequently depicted in terms of neat functionalist flow charts showing how democracy, accountability and decision making 'work'. But here too, there is a notable lack of consensus among experts when it comes to a definition. According to many leading experts, the EU is 'sui generis' - a hybrid form of 'postnational constitutionalism' that cannot be meaningfully explained in terms of conventional state-centric categories (Habermas 1998; Walker 2003). As Sbraggia (1993: 24) puts it, the EU does not fit any accepted category of governance. John Ruggie (1993:140) calls it 'the first truly postmodern international form', a notion that reinforces the idea that the EU is so novel that we lack an adequate language to describe it. Others have described it as a 'federation in the making' (Wallace, Wallace and Webb 1983:403), a 'quasi-federal entity' (Fossum 2004), a 'condominio' or 'consortio' (Schmitter 2000), and an 'extreme case of consociational democracy' (Schmitter (2004: 71).

Among these and other leading EU political theorists, it is generally agreed that the EU is unique and without parallel in history - a transnational, supranational entity that breaks new ground in terms of international law. Taking their cue from this celebration of its uniqueness, many EU officials and politicians argue that we should now abandon the traditional language of 'states', 'territories' and 'sovereignty' and speak instead of 'overlapping layers of competence' and 'economic and political spaces' tied together by the 'Community's spiderlike strategy to organise the architecture of a greater Europe.. ${ }^{3}$ This is what William Wallace (1996:439-60) famously termed 'government without statehood', an idea developed from Gary Marks et al's (1996) concept of 'multilevel governance' and increasingly popular notion of 'governance without government'. This elusive phrase 'multi-level governance' seems to have become a political shibboleth of choice among many contemporary EU theorists. As Schmitter sums it up: 'for better or worse, the EU is not a federation or a 
confederation, nor even a state, but a sui generis system of multilayered and polycentric governance' (Schmitter 2004:72).

WHAT THE EU IS NOT

While EU scholars disagree over the appropriate definition of the EU, on two points at least there appears to be some consensus. First, that the EU is unique or 'sui generis'; and second, that whatever else its historical trajectory may be leading towards, it is certainly not evolving some sort of state or federal 'superstate', as critics sometimes claim. The 'idea of a European superstate', they argue, is a political myth. Those who contend that the EU is transforming itself into a state are either wrong or else 'scare-mongering. These arguments were echoed repeatedly by European political leaders, particularly in Britain where 'federalism' is a curiously emotive and contested political concept. For example, speaking on в вС Radio 4 a few years ago, former EU Commissioner Chris Patten told listeners that the idea of Europe becoming a superstate was 'as likely as discovering the moon is made of cheese' and that those who suggest otherwise 'are barking. ${ }^{4}$ Similarly, Tony Blair, setting out proposals for closer European military co-operation - including the creation of a European Rapid Reaction Force - was careful to stress that he wanted to see the EU become a 'superpower' but not a 'superstate'. However, the distinction between these categories is far from clear.

The reasoning behind this dismissal of concerns about a European superstate goes something like this. First, it is argued that the EU cannot be a state because it lacks its own enforcement apparatus - an army and police force - which are central features of any state. Second, unlike nation-states, the EU has no direct tax-raising powers and commands less than $1.4 \%$ of GNP, a paltry figure that hardly qualifies it as a superstate. Third, the EU cannot be a state because it does not define itself as a state, nor is it recognized as a state in international law. Finally, the suggestion that the EU might be moving towards a federal superstate is dismissed as ridiculous because 'nobody in the EU wants a European superstate' and even the idea of a 'United States of Europe' is now seen as 'an anachronism' by all but a handful of 'Eurofanatics.' These are the typical arguments used by EU officials and government ministers in Britain to dismiss the question of European statehood (although the last claim is undermined by the fact that one of the latest calls for a 'United States of Europe' comes not from the 'Eurofanatic fringe' but from the Belgian Prime Minister, Mr. Verhofstadt, and is the title of his new book, which was published in December 2005). 
How should we interpret such outright refusal to engage with the debate over EU statehood? As an anthropologist and long-time EU observer, what I find interesting here is the rationality that underlies this 'politics of denial' over what the European Union has become. To call it 'unique' and 'unparalleled' or a 'constitutional anomaly' is hardly a serious or penetrating analysis. For many EU leaders and experts, the question of European state-formation seems to have become something of a taboo subject. The EU's growing resemblance to a state has become the 'elephant in the room', a problem ever present in debates about the future of European integration, but never directly acknowledged or spoken about because to do so would raise some very awkward dilemmas. However, the denial of European statehood can only be sustained if one ignores or trivializes the issue (for example, by dismissing it as absurd and its proponents as deranged) or else uses a form of discourse management that recasts the EU's emerging state-like character in more politically neutral and reassuring terms. This tends to be achieved by insisting upon a rigidly orthodox definition of the state as that 'centralized body that exercises a monopoly over the legitimate use of violence' within a given territory. This is the classical text-book definition of the state based on the classificatory schema of Max Weber. Yet while EU officials and scholars cling tenaciously to this orthodox idea of the state, there is a growing body of theoretical work that questions the limitations of this Weberian stereotype that conceives of statehood in terms of formal institutions, legitimate violence and 'bodies of armed men' (Alonso 1994; Nagengast 1994; Mitchell 1999; Scott 1998; Steinmetz 1999; Trouillot 2001; Krohn-Hansen and Nustad 2005).

The EU may not have a monopoly over the means of coercion, but neither did many pre-modern states and nor do many contemporary states; one need think only of Lebanon, Zaire, Uganda, Somalia, Mexico, Pakistan or even parts of Southern Italy for that matter. Instead, we should think of the state more in terms as an exercise in legitimation. As Mitchell (1999) and Trouillot (2001) put it, 'state-like effects' previously produced by institutions of the state have increasingly been relocated to other institutions such as NGOS, the sciences, educational systems, and global corporations - which have no obvious geographical or spatial fixity and which often by-pass the power of nation-states. In short, we need a broader conception of the state, one that focuses on the exercise of power and the actions of government, including all those everyday cultural forms and practices, rituals, activities and policies that regulate and shape the meaning and making of subjects. This is also an argument for taking cultural forms and practices more seriously when considering the operation of 
power and the modern mechanisms used to govern individuals and populations. In this respect, 'governance without government' is a useful idiom for thinking about this process. That said, 'governance' is also a protean and slippery word which, when used as a normative rather than descriptive category, tends to mystify rather than illuminate the operation of power. If EU policies and decision-making are the result of 'multiple actors' situated at 'different levels', who is ultimately responsible for those policies or accountable to voters? Without an identifiable policy 'author' it becomes difficult, if not impossible, to launch effective opposition to those policies.

POLITICAL HYBRID OR EMERGENT SUPERSTATE?

If we conceptualize the modern state in terms of its functions and effects, as writers like Corrigan and Sayer (1985), Alonso (1994), Nagengast (1994), and others have argued, it becomes easier to grasp the state-like qualities and powers of the EU. Even by conventional measures, the EU has acquired most of the trappings of a state. ${ }^{5}$ Although complex and unconventional, its institutional structures replicate those of the nation-state in several key ways. For example, the EU now has:

1. An executive arm in the form of the European Commission (a supranational institution that also has the exclusive right to initiate European legislation);

2. A Parliament, albeit politically very weak, that is constantly struggling to gain a larger role in the formulation and scrutiny of policy;

3. A Council of Ministers whose officials sit in almost permanent session in the Committee of Permanent Representatives ('COREPER') meetings in Brussels - meetings that now cover virtually every area of policy;

4. A Court of Justice in Luxembourg whose laws take precedence over national laws and whose judges have come to regard the Treaties as a constitution; and

5. A Constitution Treaty (signed but still un-ratified) that seeks to create an EU Foreign Minister with its own staff. Other key provisions of the EU Constitutional Treaty include endowing the European Union with 'legal personality', which would have give it the power to sign international treaties with third parties, and 'constitutionalizing' the EU flag, logo and anthem, as well as making May 9 official 'Europe Day'.

Added to this, the EU has its own citizenship, territorial borders, a single currency (the Euro) and an independent Central Bank (the Есв) empowered to set interest and exchange rates and monetary policy for the whole of 'Euroland'. 
What it does not yet have are direct tax-raising powers. However, if it can compel member-state governments to allocate their resources in the way the EU decides, why does it need direct taxation? Nor does it have a monopoly over the legitimate use of violence within the EU's given territory, although in recent years member-state governments have committed 60,000 troops to a European army (or 'Rapid Reaction Force') and in August 2006, the EU announced it would send 15,00o peacekeeping troops to Lebanon. The EU now also has its own embryonic FBI ('Europol') whose jurisdiction has expanded to cover all crimes involving money laundering, and a Europe-wide arrest warrant (EAW). On top of all this is the enormous regulatory power of the acquis (i.e. the corpus of EU laws, regulations and directives) with all the effects this has on the conduct of member-states' governments.

For all its unconventional features and unique qualities, the EU bears a striking resemblance to a state. William Wallace (1996) described the EU polity as 'governance without statehood' but I think it is more pertinent to ask instead whether the Europolity is not better described as 'statehood without government', or perhaps the embodiment of a new form of 'governmentality' (i.e. a form of political reason that attempts to apply 'economy' to the ordering of the state, and the myriad techniques and norms that are used to regulate human conduct and to make individuals subjects of power). In its widest sense, as Larner and Walters write, 'governmentality prompts us to consider how governing involves particular representations, knowledges and often expertise regarding that which is to be governed' (2004:2). To see the EU in these terms, however, one must move beyond both ethnographic empiricism and vacuous theoretical epithets and look at the kinds of relations of class, power and knowledge that the process of European unification is creating.

\section{CONCLUSION: EXPLAINING THE EU - THE ELEPHANT TEST}

At the outset of this paper I raised the question of the limits of ethnography in the context of anthropological debates over patron-client relations in Southern Europe and the Mediterranean. In the case of patron-client relations in Europe, the ethnographic interpretation was that these were voluntary, contractual relations between free and cooperating individuals - unequal yet inherently 'moral' ties that functioned to link the rural hinterland to the urban cores. Local brokers were effectively 'community-nation mediators'. This highly functionalist interpretation was reinforced by local ideologies of egalitarianism and 'honour' that disguised the class nature of these patron-client relations. As Davis concluded, friendship, kinship and spiritual kinship are simply 'secondary characteristics of patronage which is fundamentally no more than subor- 
dination and superordination by contract' (1977:148). In other words, those networks of person-to-person patron-client ties culminate in a wider system of class exploitation and political domination - a structural relationship between 'favour givers' and subordinate 'favour receivers'. It is only when looked at from a materialist perspective that we begin to see the systemic class nature of these relations. That was the key insight provided by the anthropological critique of functionalist ethnography. I argue that similar insights can be applied to the European Union. While EU experts and officials like to claim that the EU is a sui generis and multi-level system of governance that cannot be analysed using old-fashioned 'state-centric' categories, I suggest that much of this literature obscures rather than clarifies the nature of what the EU is - or is becoming. Seen from a materialist perspective, the EU clearly resembles a state and the new European elites that have come into being in and around the EU's supranational institutions seem to have all the key characteristics of a new class politique. Within the European Commission this is increasingly recognised, at least by some of its leading intellectuals. As one German informant in the Commission's influential 'think tank', the Cellule de Prospective, put it to me when asked whether a European public or 'demos' is emerging:

A European public has not developed to the same extent as national publics. That stems from the fact that we do not yet have European wide newspaper markets or television audiences. But there are some beginnings here. For example, for a certain class of Europeans there is the Financial Times and a European public is developing for a certain class of people. There is a certain elite which has already been Europeanized. And more and more, I think, other classes will be Europeanized. Let's take the civil servants. The first class of civil servant who were Europeanized were the diplomats in the foreign ministries. Then came the civil servants from the agricultural ministries. And by and by, even people working in the interior ministries are becoming Europeanized. ${ }^{6}$

Whether this new European elite of civil servants and experts will transform itself from a 'class in itself' to a 'class for itself' remains to be seen.

The broader theme of this article was how we might address the problem of 'ethnography on an awkward scale. Studying a large-scale, transnational organisation like the European Commission - or any complex state or bureaucracy for that matter - poses serious theoretical and methodological challenges for anthropology and exposes the limitations of empiricism. Following Descola (1992), I argued that ethnography is only the first step in the process of anthro- 
pological understanding; 'truth' does not lie at the level of empirical reality, and that the ethnographic data do not 'speak for themselves'. I also pointed out why anthropological explanation has to go beyond the (typically partisan and parochial) 'natives' point of view' or folk models. But this is not to deny or minimize the importance of ethnography or grounded study. Abstract and disembodied theories (of the kind found in much of the political science and International Relations literature) can lead to equally narrow or misleading perspectives. To describe the EU political system as 'post-national entity' or as a 'quasi-federal', 'cooperative confederation' or 'network of networks' blinds us to the emergent relationships of power, hierarchy and class in the EU. For that, we need more politically grounded, historical and materialist perspectives that can enable us to diagnose processes that lie beyond empirical observation. Successful analysis thus requires careful mediation between ethnography and theory. Paul Willis calls this 'theoretically informed ethnographic study', but one might equally call it 'ethnographically informed theoretical study'.

\section{NOTES}

1 For more detailed ethnographic accounts of life inside the European Commission, see Abélès et al 1993; McDonald 1998; Shore 2000.

2 Marx developed this argument in several key works but the most concise statement of this position can be found in the 'Preface' to his Contribution to the Critique of Political Economy, published in 1859.

3 Delors, cited in Ruggie 1993: 140.

4 Chris Patten, interviewed on ввс Radio 4's 'Today' Programme, 7 December 2000

5 As the 1933 Inter-American Convention on Rights and Duties of States defines it: 'The state as a person of International Law should possess the following qualifications: (a) a permanent population; (b) a defined territory; (c) government; and $(d)$ the capacity to enter into relations with other states' (Osmañczyk 1990: $871)$.

6 Fieldwork interview with Thomas Jansen, (political scientist and former official in the Secretariat of the European People's Party in Brussels), working for the European Commission's Cellule de Prospective, 20 June 1996. 


\section{REFERENCES}

Abélès, M., Bellier, I. and McDonald, M. 1993. 'Approche anthropologique de laCommission Européene', Brussels: European Commission.

Alonso, A. 1994. 'The Politics of Space, Time and Substance: State Formation, Nationalism, and Ethnicity', Annual Review of Anthropology, 23:379-405

Asad, T. 1972. 'Market Model, Class Structure and Consent: A reconsideration of Swat political organisation', Man (N.S.) 7: 74-94.

Bailey, F. G. 1971. 'Gifts and Poison' in his Gifts and Poison: The Politics of Reputation, Oxford: Blackwell: 1-25.

Boissevain, J. 1974. Friends of Friends: Networks, Manipulators and Coalitions, Oxford: Blackwell

Brown, K. 2005. The Ethnography of Democracy Promotion, Anthropology News November: $26-27$

Campbell, J. 1966. Honour, Family and Patronage. A study of Institutions and Moral values in a Greek Mountain community, Oxford: Clarendon.

Colclough, N. 1975. 'Social Mobility and Social Control in a Southern Italian Village' in F. G. Bailey (ed) Gifts and Poison, Oxford: Blackwell: 212-30.

Comaroff, J. and Comaroff J. 2003. 'Ethnography on an Awkward Scale', Ethnography 4 (2): $147-79$

Corrigan, P. and Sayer, D. 1985. The Great Arch. English State Formation as Cultural Revolution, Oxford: Blackwell.

Cutileiro, J. 1971. A Portuguese Rural Society, Oxford: Clarendon Press.

Davis, J. 1975. 'Beyond the Hyphen. Notes and Documents on Community-Nation Relations in South Italy', in J. Boissevain and J. Friedl (eds) Beyond the Community. Social Processes in Europe, The Hague: Ministerie van Ouderwijs en Wetenschappen.

Davis, J. 1977. People of the Mediterranean, London: Routledge and Kegan Paul. 
Descola, P. 1992. 'An Interview with Philippe Descola', Anthropology Today, 8 (2) April: 9-13

Fossum, J. 2004. 'Still a Union of deep diversity? The Convention and the Constitution for Europe', in E. Eriksen, J. Fossum and A. Menendez (eds) Developing a Constitution for Europe, London: Routledge.

Habermas, J. 1998. The Inclusion of the Other, Cambridge, Mass: MIT Press.

Kenny, M. 1968. 'Parallel Power Structures in Castille. The Patron-Client Balance', in J. G. Peristiany (ed.) 1968, Contributions to Mediterranean Sociology, The Hague: Morton pp. 155-62.

Krohn-Hansen, C. and Nustad, K. (eds) 2005. State Formation: Anthropological Perspectives, Ann Arbor/London: Pluto

Li Causi, 1975. 'Anthropology and Ideology: The Case of Patronage in Mediterranean Societies', Critique of Anthropology, 4-5 (Autumn): 90-110.

Marks, G. et al 1996. 'European Integration from the 1980s: State-Centric v. Multilevel Governance', Journal of Common Market Studies, 34 (3):341-378.

McDonald, M. 1998. Anthropological Study of the European Commission, Unpublished Report prepared for the European Commission ('Forward Studies Unit'), Brussels: European Commission.

Mitchell, T. 1999. 'Society, Economy, and the State Effect', in G. Steinmetz (ed.) State/Culture, Ithaca: Cornell University Press: 76-97.

Nagengast, C. 1994. 'Violence, Terror and the Crisis of the State', Annual Review of Anthropology, 23:109-36.

Osmañczyk, E. 1990. Encyclopedia of the United Nations and International Relations, New York: Taylor and Francis.

Peristiany, J. G. (ed.) 1968. Contributions to Mediterranean Sociology, The Hague: Morton

Pitt-Rivers, J. 1961. The People of the Sierra, Chicago: Chicago University Press 
Puchala, D. 1972. 'Of Blind Men, Elephants and International Integration', Journal of Common Market Studies, 10, (3):267-284.

Ruggie, J. 1993. 'Territoriality and Beyond: Problematizing Modernity in International Relations', International Organisations, 47 (1):137-74

Sbragia, A. 1993. 'The European Community: A Balancing Act', Publius, 23 (Summer): $23-38$.

Schmitter, P. 200o. How to Democratize the European Union ... And Why Bother?, Lanham, Md.: Rowman and Littlefield.

Schmitter, P. 2004 'Democracy in Europe and Europe's Democratization', Journal of Democracy, 14 (4): 71-85

Scott, J. C. 1998. Seeing Like a State: how certain schemes to improve the human condition have failed, New Haven; London: Yale University Press

Shore, C. and Wright, S. 1997. Anthropology of Public Policy: Critical Perspectives on Governance and Power. London and New York: Routledge.

Shore, C. 200o. Building Europe: The Cultural Politics of European Integration, London/New York: Routledge.

Silverman, S. 1965. 'Patronage and Community - Nation Relationships in Central Italy', Ethnology, 4 (2):172-89.

Steinmetz, G. (ed.) 1999. State/Culture. State-Formation after the Cultural Turn, Ithaca and London: Cornell University Press.

Trouillot, M-R. 2001. 'The Anthropology of the State in the Age of Globalization: Close Encounters of the Deceptive Kind', Current Anthropology, 42 (1) February:125-138.

Walker, N. 2003. 'Postnational Constitutionalism and the Problem of Translation', in J. H. Weiler and M. Wind (eds), European Constitutionalism Beyond the State, Cambridge: Cambridge University Press.

Wallace, W. 1996. 'Government without Statehood: The Unstable Equilibrium', in H. and W. Wallace (eds) Policy-Making in the European Union, Oxford: Oxford University Press. 
Willis, P. 2002. 'TIES: Theoretically Informed Ethnographic Study', in S. Nugent and C. Shore (eds) Anthropology and Cultural Studies, London: Pluto, pp. 182-92.

Wolf, E. 1966. 'Kinship, friendship and patron-client relations in complex societies', in M. Banton (ed.) Social Anthropology of Complex Societies, ASA Monograph, 4, London: Tavistrock:1-22.

Wedel, J. Shore, C., Feldman, G. and Lathrop S., 2005. 'Towards an Anthropology of Public Policy', The Annals of the American Academy of Political and Social Sciences, 600, (July):30-51. 